\title{
TRTaKadeMi
}

ISSN 2149-9446 | Cilt 06 | Sayı 11 | Ocak 2021 |Büyük Veri

\section{Büyüyen Veri Küçülen İnsan: Şimdileşen Geleceği Kara Ayna'da Seyretmek}

\author{
SERTAÇ T. DEMIR
}

\begin{abstract}
Öz
Kovid-19 pandemisiyle ivmelenen ve bir bakıma meşruiyet kazanan sanal trendler, artk etrafimıza örülen küresel bir ağı değil; eylemlerimize, düşüncelerimize, hatta bilincimize ve ruhumuza sinen yeni bir insanlık durumunu ifade etmektedir. Geldiğimiz noktada, adına büyük veri denen ve kendi aleyhimize kullanılmaya meyli ve kudreti olan bir şeyi bizzat kendi ellerimizle büyüttüğümüzü fark ediyoruz. Her geçen saniye katlanarak büyüyen ve tümüyle bizden taşan bu dijital görünümlerin gün gelip de salt kötülük üretmeyeceğinden emin olabilecek miyiz? Şurası açık ki algoritmalarla şekil bulan bu devasa portrenin yeni bir dünya tasarlama meşruiyeti yoksa bile, fazlaca imkânı bulunmaktadır. Nitekim bizimkisi, "Yapabiliriz." eyleminin "Öyleyse yapmalıyız." sözüne temel oluşturduğu bir çağdır. Öte yandan, büyük veriye öncülük eden odakların, son birkaç yıldır iyiden iyiye yükselen, "İnsan iradesine, özgürlüğüne ve mahremiyetine ne olacak?" sorusu hakkında açık ve güçlü bir yanıt vermemiş olmaları nasıl yorumlanmalıdır? Bu çalışma, takip ettiği akademik geleneğin kendisine yüklediği sorumlulukla meseleyi "insanın akıbeti" sorunsalına getirmekte ve büyüyen verinin modern insanın küçülmesine eşlik ettiğini öne sürmektedir. Bu amaçla, büyük veri ile modern insan arasındaki yapıcı/yıkıcı ilişki Netflix yapımı Black Mirror dizisinin Nosedive adlı epizotu üzerinden ele alınmakta ve Günther Anders, Jean Baudrillard, Zygmunt Bauman ve Byung Chul-Han gibi dikkat çekici düşünürlerin teorileri etrafinda incelenmektedir.
\end{abstract}

Anahtar Kelimeler: Büyük Veri, İnsan, Dijital Kültür, Özgür İrade, Değişim, Black Mirror

\section{Araştırma Makalesi}

Geliş Tarihi: 26.10 .2020

Kabul Tarihi: 05.01.2021

ORCID ID: 0000-0002-9420-9416 DOI: 10.37679/trta.816681

E-mail: stdemir@gumushane.edu.tr 


\title{
TRTaKadeMi
}

ISSN 2149-9446 | Volume 06 | Issue 11 | January 2021 | Big Data

\section{The Growing Data and Shrinking Human: Watching the Nowist Future Through the Black Mirror}

\author{
SERTAÇ T. DEMIR
}

\begin{abstract}
Virtual trends that have gained momentum and legitimacy with the COVID-19 pandemic are no longer a global network woven around us; rather it expresses the new human condition that permeates our actions, thoughts and even our consciousness and soul. At the point we have reached, we have just realised that we have enhanced with our own hands something that has power and tendency to be used against ourselves, which this is called big data. Can we be sure that these digital appearances, which grow exponentially with each passing second and completely overflow from us, will not produce pure evil when the day comes? Obviously, this gigantic portrait, shaped by digital algorithms, has many possibilities, even if it has no legitimacy to design a new world. Indeed, ours is the era when the action "we can" underpins the saying "Then we should do it". Besides, how should it be interpreted that the pioneers of Big Data have not given a clear and strong answer to the question of "what will happen to human will, freedom and privacy", which has been rising for the last few years? This study, with the responsibility imposed by the academic tradition it follows, gathers the issue around the problem of "human fate" and asserts that growing data accompanies the shrinkage of the modern human. For this purpose, the constructive/destructive relationship between big data and modern human is dealt with through the episode titled Nosedive of Netflix's Black Mirror series and examined around the theories of significant thinkers such as Günther Anders, Jean Baudrillard, Zygmunt Bauman and Byung Chul-Han.
\end{abstract}

Keywords: Big Data, Human, Digital Culture, Freewill, Change, Black Mirror

Research Paper

Recieved: 26.10 .2020

Accepted: 05.01.2021

ORCID ID: 0000-0002-9420-9416 DOI: 10.37679/trta.816681

E-mail: stdemir@gumushane.edu.tr 


\section{Giriş}

Bilim kurgu klasiklerinden Black Mirror dizisinin Nosedive (Dibe Vuruş, 2016) adlı bölümü, içinde bulunduğumuz distopik kurgunun etkili bir hicvidir (Gilbert, 2017). Bu bölümde yaşananlar panoptikonun dijital bir versiyonu (Urueña and Melikyan, 2020: 85) ve kusursuzluk arayışlarıyla gelen yıkııı bir dünyanın tasarımıdır (Virani, 2019). Yönetmenliğini Joe Wright'ın yaptı̆̆ film, insanların gözlerindeki implantlar yoluyla birbirlerinin dijital kimliklerini görebildikleri ve sürekli ellerinde gezdirdikleri mobil cihazlarla birbirlerini puanlayabildikleri bir yeni-toplum kurgusunu resmetmektedir. Herkesin bir diğerinin yazgısı olduğu bu "gelecek zaman portresi"nde ${ }^{1}$ birden beşe kadar verilen her puan, insanların sosyal ve ekonomik statülerini tayin etmektedir. Bu yazgıda büyük veri, insanların -aracısız bir şekilde- birbirlerini hem inşa hem de imha ettikleri bir erdem parametresine dönüşmektedir. Hemen herkesin hem yönetildiği hem de bir tür yöneticiye evrildiği bu işleyişte, sistemin mutlak bir sahibi bulunmamaktadır. Bunun yerine yüksek puan toplamanın stratejilerini istatistikleyen "veri danışmanları" vardır. Dolayısıyla buradaki asıl zorlu rekabet insanın kendisiyledir ki insanlardan devamIı yüksek performanslar sergilemeleri, "paylaş" butonunu aralıksız aktif tutmaları ve "beğeni" ibresini kendi lehlerine çevirmeleri beklenmektedir. Nosedive' in baş kahramanı Lacie'nin de hem toplumun dışına itilmemek hem de arzuladığı yaşama kavuşabilmek için uyması gereken ilk kural budur.

Film, hiçbir şeyde olağan dışılığın görünmediği muhteşem derece pürüzsüz; dolayısıyla aşırı yapay bir sokakta elindeki telefona bakıp bir şeylere aralıksı dokunarak koşan Lacie'nin görüntüsüyle başlar. Birkaç saniye sonra kadraja "gözleri ve elleri telefonda olan" diğer insanlar girer. Gerçeğin, siber uzay boşluğunda eritildiği bu kurgu-mekândaki insanlar sanki aynı şeyi yapmaya programlanmış sayborgları andırmaktadır. Nosedive, herkes için geçerli olan akıcı düzenin toplumdaki her bir bireyin diğerine layık gördüğü geri bildirimlerle belirlendiği yeni bir insanlık durumunu ifşa etmektedir. Bu düzen, hiç şüphesiz toplama, yığma, yorumlama ve sınıflandırma çabasıyla yaşamı dijital formda sürgit-şifreleyen büyük verinin de özüdür. David Le Breton haklıdır: "Siber uzay, kendini tutkuyla burada ifade eden kişiye, "gerçek yaşamın" hemen orada, parmağının ucunda olduğu ve sıradan hayatta bedenin değişmez biçimde cisimleştirdiği kişisel egemenlik sınırlarının burada kökünden kaldırılıp atıması sayesinde, kendi keyfine göre bir

\footnotetext{
${ }^{1}$ Esasında Büyük Veri üzerinden geliştirilen benzer bir uygulamaya Çin'de yasal olarak başlanmıştır. Sosyal Kredi Sistemi olarak tanımlanan bu derecelendirme, insanları kişilik özellikleri, toplumsal davranışları, diğer insanlarla ilişkileri, finansal durumları ve sosyal statüleri bakımından sınıflandırmayı önermektedir (Vincent, 2017).

${ }^{2}$ italik vurgu bana ait.
} 
sanal varoluş inşa etme imkânının olduğu duygusunu vererek dünya ile ilişkisini kuşatmaktadır" (2016: 150). Dolayısıyla gerek gündelik kültür gerekse bu kültürü emen büyük veriyi artık dış dünyayı yapılandıran bir ağdan ziyade varoluşa nüfuz eden içkin bir bağ olarak görmenin tam vaktidir.

Yakın gelecekte her şeyin büyük veri tarafindan üretileceğini öngören Büyük Verinin İnsani Yüzü (The Human Face of Big Data, 2014) ${ }^{3}$ adlı belgeselde, büyük verinin gidişatına özet teşkil eden şu ifadelere yer verilmektedir: "15. yüzyıldaki atalarımızın tüm ömürleri boyunca maruz kaldıkları bilgiyle bizler yalnızca bir günde karşılaşıyoruz. Fakat dikkat etmek zorundayız. Çünkü bu devasa veri okyanusunda, korkutucu bir şekilde tam olarak bizler varız: Nerede yaşadığımız, nereye gittiğimiz, ne satın aldığımız, ne söylediğimiz, tüm bunlar kaydedilmekte ve depolanmaktadır, üstelik sonsuza kadar." Telefon numarası ve adres gibi kişisel bilgilerimiz, ilişkilerimiz, alışkanlıklarımız, konum bilgilerimiz, IP adreslerimiz, kariyer geçmişimiz, nelerden hoşlanıp nelerden hoşlanmadığımız, fotoğraflarımız, videolarımız, mesajlarımız, yorumlarımız ve etiketlerimizin her biri artık büyük verinin en kritik bileşenlerini oluşturmaktadır. Dahası, veri toplayan binlerce uygulama dışında, önümüzdeki on yılda yüz milyardan fazla cihazın ve trilyonlarca sensörün yaşama internetle bağlanmış her şeyden veri akışını inanılmaz boyutlara taşıyacağı düşünülmektedir (Franklin, 2019: 80-81).

\subsection{Yaklaşım ve Yöntem}

Bu çalışma, bir bilim kurgu eseri olan Nosedive adlı epizotla gündeme gelen büyük veri ve insan hâlleri üzerine odaklanmaktadır. Nitekim sinemanın kendisi toplumsal gerçekliğin en derin katmanlarıyla görünür olduğu projektörlerden biridir (Diken ve Laustsen, 2016). Bu açıdan, bizatihi filmin kendisini analize kalkışmadan filmin göndermelerine yoğunlaşılmaktadır. Başka bir ifadeyle filmin tüm teknik detaylarıyla beraber filmin kendisi değil; büyük veriye dair sunduğu önermeler analiz edilmektedir. Sinema sanatı ile toplum bilim arasındaki bu ortaklık, yalnızca filmlerin hayata dair mesajlar taşımasıyla ilgili değildir. Aksine, yaşadığımız çağda hayatın kendisi gittikçe sinemasallaşmaktadır. Sinema -tıpkı bilim, bilgi ve teknik gibi- düşselin alanı içine girmişse de (Baudrillard, 2006b: 42); düşsellik de sinemaya özgü nitelik kazanmıştır.

Bilim kurgu da artık yalnızca izlenen bir görüntü olmaktan çıkmış, bizzat yaşadığımız şeye dönüşmüş durumdadır. Her bölümüyle izleyicileri durumsal ikilemlerin içine atan Black Mirror dizisi bir taraftan tedirgin edici gerçekleri ifşa ederken di-

\footnotetext{
${ }^{3}$ Türkiye'de birçok üniversitede çeşitli etkinliklerle analizleri yapılan bu bol ödüllü belgeseli izlemek için bkz. https://www. youtube.com/watch?v=4VeITe6EJDU
} 
ğer taraftan insan-teknoloji ilişkisinin gelecek-zaman varsayımlarını sorgulamaktadır (Johnson, Marquez and Urueña, 2020: 3-4). Dizinin hemen her epizotunda görülen ortak şey, tüm hikâyenin kusursuz bir evren tasarımıyla başlayıp sonunda bu kusursuzluğun felaketle nihayetlenmesidir. Black Mirror'da her ütopik plan ve umut, eninde sonunda kaçınılmaz bir distopyaya evrilmektedir.

“Teknolojinin nötr olduğu”na dair geliştirilen mit (Bauchspies, Croissant ve Restiuo, 2019: 139) bu makalede bir tenkit konusudur. Zira sosyal değişmeyi güdüleyen teknolojinin (Toffler, 1981), gözlemlenebilir sonuçlara ulaşıldıkça taraflı bir dünya perspektifi arz ettiği anlaşılmaktadır. Bu farkındalığı geliştirmek için teknolojiyi, Lee'nin önerdiği gibi (2019: 24), "her zaman orada varmış gibi” kabul etmek yerine onun bu noktaya nasıl ulaşth̆ını tartışmak gerekmektedir. Buradaki anlamak fiili, en azından bu kadar yakın -yani neredeyse dışına içinden bakılan bir meseleyi kavramak yolunda oldukça çetin bir iştir çünkü Baudrillard’ın incelikle ifade ettiği gibi (2006b: 69), "Aslında ancak belli bir uzaklıktan bakıldığında bir anlam kazanan gerçeğe bizler haddinden fazla yaklaştırılmaktayız." Bu minvalde makale, büyük veriye dair bir tür "üzerine düşünme girişimi" olarak tanımlanabilir.

Bu çalışmada elbette değerleri aşındıran hıza, hissedişsiz eylemlere, yaşamasız mekânlara, mekanikleştirilen zamana ve olancasına -bedenileştirilen yeni mekanik veri-insan modeline dair belirgin bir karşı duruş vardır. İletişim bilimleri, görsel kültür ve sosyoloji ekseninde geliştirilen bu karşıtlık, büyük verinin kendisinden ziyade, bizatihi bu veriyi inşa eden ve inşa ettiği şeye, yani karşısında her geçen gün biraz da nicelikleştirilerek küçülen modern insanın izdüşümlerine yönelmektedir. Bu sorgulama, esasında şu soruda somutlaşmaktadır: Her şeyin doğrudan ya da dolaylı olarak bir istatistik parametresine dönüştüğü performatif ve kontrolcü veri toplumunda insana ne olacaktır? Bu soru, "Büyük verinin kullanılış biçimi itibariyle varoluşçu ontolojinin sınırlarını daraltması" (Ertürk, 2019: 167) nedeniyle hem geçerli hem de güncel bir sorudur. Öyle ki, örneğin Nosedive'de de insanların, topladıkları puanlarla şekillenen e-profiller dışında, kendilerini tanımlayabilecekleri insani vasıflar kalmamıştır.

Büyük veri, öte yandan, geliştirdiği kolektif eylem örüntüleri içinde, insana bir birey olarak kendisine dair henüz fark etmediği birtakım ontolojik nitelikleri keşfetmesine de olanak sağlamaktadır (Chul-Han, 2020: 72). Elbette bir yığın olarak toplanan hiçbir veri, "Ben kimim?" sorusunu karşılamaya yetmeyecektir çünkü kendilik denilen şey, kişinin kendini bulmasını sağlayacak bir anlatıya mecburdur (Chul-Han, 2020: 67). Gelinen noktada, Büyük verinin böylesi bir anlatıyı gitgide büyüyen bir etkiyle insanlar üzerinden ama insansız olarak -ya da en azından insanı olabildiğince küçültmeye çalışan bir edayla ve otomasyon mantığı içinde 
kendi başına kurmaya çalıştığı söylenebilir. Bu çaba ve eğilim, büyük verinin göz ardı edilmesi mümkün olmayan en sıcak sorunsallarından biri, belki de en esaslısı değil midir? Bu açıdan, Lacie'ye istisnai bir film kahramanından çok, neredeyse hepimizin içinde oynadığı küresel bir kurgunun temsili olarak bakmak daha yerinde olacaktir.

Bu eksende, makale boyunca yanıt aranacak sorular şöyledir: Büyük veri, yaşama ve insana nasıl bir anlam yüklemektedir? Büyük verinin meşruiyet zemini nedir? Veri hangi yollarla toplanmaktadır? Toplanan verinin nesnesi olan insan, süreç sonunda neye dönüşmektedir? Büyük verinin tecellileri insanın etrafinda mı, yoksa iç dünyasında mıdır? Insanın sistemin içinde kalmayı sürdürmesinin ve onu sürekli beslemesinin motivasyonu nedir? İnsan, ürettiği şeyin karşısında neden ve nasıl ters köşe olmaktadır? Özgürlüğün dahi bir esaret aracı formu aldığı bu işleyişte, insanın kendisi olabileceği bir evren ya da tavır var mıdır? Nosedive dizisi, tüm bu konularda ve özellikle de özgürlük arayışında izleyiciye ne tür bir öneri sunmaktadır?

\section{Analiz}

\subsection{Arka Plan ve Perspektif}

Büyük veri eksenindeki büyük dönüşüm, hiç şüphesiz, geleceğin kaçınılmaz imgesi gibi durmaktadır. Nitekim büyük veride büyük olan tek şey verinin kendisi değil, verinin etkisidir (Chen, Chiang ve Storey, 2012). Bu tespit, Antik Yunan tragedya yazarlarından olan Sofokles' in, "Muazzam hiçbir şey lanetini yanında getirmeden ölümlülerin hayatına girmez." ${ }^{4}$ varsayımını doğrulamaktadır. Kancaya Takılınca adlı kitabın yazarı Nir Eyal de aynı minvalde, bir okurunun şu vurgusunu paylaşmaktadır: "Bir şeyin kötü bir amaçla kullanılması mümkün değilse süper güç olması düşünülemez." (2015: 19). Büyük verinin bu denli karşıt ve yer yer abartılı tartışmaların odağında yer alması ve ağırlıkla tekinsiz olmakla itham edilmesinin ardında, belki de onun "her şey olmaya müsait" esnek ve anonim doğası vardır. Toplanan verinin hangi etkiyi yaratmak adına işe koşulacağıyla ilgili etik boşluklar da mevcuttur. Üstelik bu soru işaretlerini gidermesi beklenebilecek kesin muhatapların olmaması bu boşluğu fazlasıyla derinleştirmektedir. Nosedive'de de sistemi idare edenin kim olduğuna dair herhangi bir bilgi verilmemiştir. Büyük verinin sonuçlarının devasalığı, muhatabın kimliklerini silikleştirmektedir belki de.

\footnotetext{
${ }^{4} Y$ ine bir Netflix yapımı olan ve sosyal ağların insanlar üzerindeki etkilerini gündeme getiren Sosyal ikilem (The Social Dilemma, 2020) adlı belgesel de Sofokles'in bu sözleriyle başlamaktadır.
} 
Sonsuz Dikkat Dağınıklığı kitabının yazarı Dominic Pettman da (2017: 39), böylesi bir muhatabın her hâlükârda salt belli bir merkeze ya da tek bir ofise indirgenemeyeceğini belirttikten sonra, asıl amacın yaşam değil, kâr olduğunun altını çizmektedir. İktidar tartışmalarını alevlendiren bu belirsizlik, esasında iktidar sosyolojisinin yeni bir nosyonu olarak kabul görmektedir. Örneğin Michel Foucault için iktidar, belli bir özneden ziyade ilişkilere gönderme yapmaktadır. ${ }^{5}$ Zygmunt Bauman'a göre de (2010: 95), hızla ve karmaşa içinde küreselleşen ve siyasetin yükümlülüklerinden çıkan iktidarın en dikkat çekici özelliği, yokluğudur. Buradaki yokluk ifadesi, görülmediği hâlde gören bir gözün varlığını ima etmektedir. "Sürekli bakan, kaydeden, izleyen ve kapanmayan (bu) göz" merkezden kopup uzamı tümüyle kaplamıştır (Yıldırım. 2019: 72).

Büyük veri tartş̧malarına dâhil olmaya ömrü yetmemiş olsa da sosyolog Jean Baudrillard belki de her teknoloji eylemi için geçerli olabilecek güçlü bir uyarıda bulunmuştur. Ona göre (2006a: 23), kendi nedenlerinden kurtulan bütün sonuçlar sapkınlaşır. Bugün, büyük veri gibi, ilerlemeyi vaad eden tüm diğer benzer tekno devrimlere de uyarlanabilecek bu olasılık, tam da Baudrillard'ın sorguladığı şekilde, araçların, üretilme nedenlerinden sapma eğiliminde olduğunu düşündürmektedir. Üstelik bu eğilim, araçların her geçen gün biraz daha kalabalıklaşması ve bunun sonucu olarak paradoksal biçimde görünmezleşmesiyle karmaşıklaşmaktadır. En önemlisi aygıtlar, kendilerini kullanan insanları, teknolojik etkinin sonuçlarını okuma becerisinden yoksun bırakacak bir zihin-bulanıklığına ve yüzeyselliğe sürüklemektedir.

\subsection{Büyüyen Veri}

Büyük veri, öncelikle monitörizasyon (izleme) ya da akümülasyon (biriktirme) girişimiymiş gibi görünse de ve bu varsayımla yürütülse de gerçekte ham veriyi yorumlayarak işlevselleştirme teknolojisidir. Büyük verinin gittikçe ulvileşen bu pragmatist dokusu dataizm kavramında somutluk kazanmaktadır. Dataizm, tıpkı otokrasi gibi (ama özgürlük otokrasisi), Harari'nin tanımladığı gibi (2016: 383), evreni veri akışından ibaret görmekte ve hayattaki her şeyin veri işleme sürecinin bir parçası olduğunu ileri sürmektedir. Byung Chul-Han’a göre (2019: 81), toplu davranış kalıplarını görünür kılan büyük verinin gölgesinde dataizm de aynılaşmayı güçlendirerek arttırmaktadır. İnsanları biyometrik kimlikler olarak yeniden-kodlayan dataist tavır, davranışları önceden kestirmenin de bir adım ötesinde pozisyon almaktadır. $\mathrm{O}$, insan davranışlarında ve tercihlerinde hem sadık hem de esnek değişimlerin nasıl sağlanacağına dair kâr marjı yüksek stratejiler önermekte ve üretmektedir.

\footnotetext{
${ }^{5}$ Foucault'un iktidar anlayışına dair röportajı izlemek için bkz.: https://www.youtube.com/watch?v=N3nU44c5578
} 
Bu trend, her şeyi kontrolü altında tutmayı önceleyen ve bu maksatla nokta atışlı şablonlar üreten modern kültürle uyum içindedir. Söz konusu şablonlar, veri havuzuna kendi elleriyle su taşıyan modern bireyler için tam da arzulandığı sanılan simülatif yaşamı deneyimlemenin keyfini sunmaktadır. Üstelik Bauman'ın ironik bir ifadeyle tasvir ettiği gibi (2018: 149), yolunu kaybetme korkusunu iliklerine kadar duyumsayan bu modern bireylerin, aşina oldukları her şeyle teskin olmaya daima aç ve açık olduklarını eklemek gerekmektedir. Teknolojikleşmiş modernlerin, tıpkı Lacie gibi, sürekli farklı şeyler yapmanın özlemini dile getirdiği hâlde, benzer ortamlardaki belli alışkanlıklara takılı kalmasının zımni gerekçesi bu olabilir.

Büyük veri, savruk bir yığından istendik kriterler ışığında kâr edici ve sonuç alıcı bilgiyi/yöntemi/stratejiyi çıkarma oyunudur. O, tıpkı küçük bir çocuğun dil öğrenirken topladığı kavramlar gibi, ilgili ilgisiz her şeyi bünyesinde toplayan bir mıknatısı andırmaktadır. Topladığı şeylerin kaynaklarına dair de herhangi bir sınırlama getirmemektedir. Öyle ki istediğini bir insanın kalp atışlarından ya da arkadaşıyla buluşmaya giden birinin otomobilindeki navigasyondan eş zamanlı elde edebilmektedir. Bu sayede bir sonraki durumlar için tecrübeyle sabit öngörüler -Yoksa içgörü mü demeli?- üretmektedir. Örneğin topladığı kalp atı̧ı ritminden kalp krizi riskini ya da otomobildeki kişinin kaza olasılığını hesaplayabilmektedir.

Bu öngörü/içgörü bir taraftan onun varlığına meşruiyet kazandırırken diğer yandan takındığı sınır tanımazlığa dair genişleyen endişeye kaynaklık etmektedir. Baudrillard'ın sanal makineler hakkında ifadelendirdiği gibi (2005: 82) burada her şeyi verirmiş gibi yapıp aslında her şeyi alıp götüren bir takas söz konusudur. Bu takasa dair imzalanan sözleşmenin kavramları sisli olduğu gibi, metnin kendisi hıza müptela kullanıcının irdelemeyeceği kadar meşakkatlidir. Bu nedenle Ahearn'ün önerdiği gibi (2012: 39), "onay sözleşmesi”ne ya da "paylaş" düğmesine basmadan önce iyi düşünmek gerekmektedir ki daha sonra iptal edilse bile internette hiçbir şey kaybolmamakta ya da sil baştan geri alınamamaktadır. Aktarılan her veri, siber uzayın yer çekimsiz atmosferinde alıcısını bekleyen bir iştahla salınmaktadır.

Büyük veriye biteviye akış sağlayan modern bireyin, bunca riske rağmen, bu denli tutkulu onaylar ve paylaşımlar içinde olması akıl dışı görünebilir. Ne var ki sanal makineler aleminde rasyonellik, üretilen yoğun duyguların yanında varlığı önemsenebilecek ya da yokluğu fark edilebilecek belki de son şeydir. Nitekim buradaki işleyiş, aklın doygunlaşmasından ziyade duyguların tatminine dönüktür. En azından bu akışın kurguladığı "dikkat iktisadı", arzuların bilgiyi alt ettiği bir düzeni yüceltmektedir (Pettman, 2017: 24-25). Başka bir bakışla, bireylerden akan bilgi akışının öncesinde, bu bireyleri orada tutan ve her an paylaşmaya teşvik eden ne- 
redeyse karşı konulamaz bir duygulanım hâkimdir. Fakat bu süreç, sürdürülebilir olmadığı sürece, verinin tabiatı olan karşılaştırma yapabilme ve değişimi izleyebilme niteliklerinden muaf kalacaktır. Bu nedenle, eylemlerin duygulanımlara; onların da önce alışkanlıklara sonra da bağımlılıklara dönüştürülmesi gerekmektedir. Kancaya takılması umulan kişilerin, her gün daha da artan bir etkiyle bağımlılık yaratacak ürünler ve hizmetlerle karşılaşmalarının (Eyal, 2015: 10) nedeni büyük oranda budur. Lacie'de izlenen bağımlılıklar ise insanlığın belki de gelebileceği son noktalardan birini işaret etmektedir ki o da artık bağımlılıkların eylemleri aşıp yaşamın ve varlığın içini doldurmasıdır. İnsanın kendisinin bir bağımlılık yumağı olarak yeniden üretildiği bir toplum formunda, hiçbir bağımlı eylemin, onarılması gereken bir anormallik taşıyıp taşımadığının sorgulanmamasına şaşılmamalıdır. Veri akışının öncülü olan bağımlılıklar, artık bu çağın normudur.

Bu açıdan büyük veri, kendi dışındaki hemen her teknik gelişmenin bir tür toplam çıktısı ya da kesişme noktası olarak değerlendirilebilir. Şayet küresel bir zihnin inşa edilmesinden bahsedilecekse esas itibariyle tüm teknolojilerin yalnızca kendi içlerindeki nitelikleriyle değil, diğer araçlarla bağlantılarıyla beraber okunması gerekmektedir. Nitekim gerek bireyler gerek toplumlar ve gerekse kurumlar, artk ortak değer yargılarından ziyade, kendilerini dış dünyaya bağlayan internet örüntüleriyle birbirlerine yak(ın)laşmaktadırlar. Teknolojiyle temas içinde olan eylemlerimiz, -ki bunun dışında bir eylem alanı kaldı mı!- paylaşım amacı taşısın ya da taşımasın, gündelik yaşamda bıraktığı dijital izlerle tasnif edilmektedir. Bu izlere, çağın gerçek zamanlı yeni parmak izleri denebilir. Asırlarca uzayı izleyen, fezaya merak salan insanoğlu, bugün (siber) uzaydaki uyduların gözetimi ve diğer insanların taşıdıkları araçların kontrolü altındadır. Peki bu, yalnızca Nosedive dizisindeki kurgu karakterler haricinde, içinde istisnasız herkesin bulunduğu ya da bulunmaya oldukça yakın durduğu devasa bir kitlenin ve küçülen insanın sorunu değil midir?

\subsection{Küçülen İnsan}

Herkesin bir avatarını tasarlayan kolektif düzenekte her birey, kendine has zafiyetlerinden ve alışkanlıklarından yakalanmaktadır. Pettman bu durumu örümcek ve sinek metaforu üzerinden açıklamaktadır (2017: 66). Ona göre, Silikon Vadisi'nde tasarlanan algoritmaların köleleri olan sıradan insanlar, tıpkı avlayacağı sineğin özelliklerine uygun yapışkan ağlar ören örümceklerin tehdidi altındadır. Fakat Pettman'ın bahsetmeyi ihmal ettiği paradoks, bu ağlara yapışmış sineğin kendisi hakkında yaptı̆̆ yorumlamaya dairdir. Oysa sineğin trajedisi, kendini ağ üstünde özgür sanmasındadır. Sineğin dilediğince uçuşu bile, eninde sonunda 
yorgun düşüp konacağı yerde onu bekleyen kaçınılmaz sona hizmet etmektedir. Modern birey de geliştirmesine müsaade edilen ışıltılı özgürlük söylemlerinin perde arkasında, her gün aynı şeyi tecrübe etmeye mecbur bırakıldığı dramatik bir esarete mahkûmdur.

Yaptığı yorumların ve izlemelerin ardından kendisine salık verilen ürünleri satın alırken duyumsadığı bu sahte ve zorba özgürlük hissi de aynı paradoksun uzantısıdır. Jonathan Crary, bu paradoksun gölgesinde gözetleme ihlallerine boyun eğen bu modern insanları "uysal tebaalar" olarak tanımlamaktadır (2015: 65). Doğrusu makineler aracılığıyla imal edilen tek şey başka makineler değildir artık. Özgürlük, mahremiyet ve iradenin dijital tasarımlanması sonucunda insan da gittikçe bir imalat metaına dönüşmektedir. İnsan Sonrası kitabının yazarı Rosi Braidotti'ye göre günümüz insanı, kâr odaklı teknolojinin dolayımında nesneler statüsüne indirgenen bir metalaştırmaya muhataptır (2018: 130). Böyledir çünkü ne olmak-istediğini bilemeyen ve olduğu-gibi kalamayan insan, artık yalnızca bilinç dışı ya da edilgen edimlerden ibarettir.

Teknoloji çağında içerikler, ürünler tarafindan üretilmektedir (Anders, 2018b: 230). Bunun için bireyin yapması gereken tek şey, bu hazır akışa engel olmamak; yani hiçbir şey yapmamaktadır. Kendi başına bir internet bağlantısına dönüşen modern birey için (Bauman ve Lyon, 2016: 20), en küçük e-talimatlar bile büyük başlangıçlara kapı aralamaya yetmektedir. Unutkanlığı olmayan ve şeyleri biriktirerek toplayan bir bulutun belleği karşısında, insan hafizası da işlevsizleştirilmektedir. Dolayısıyla kendimize dair verileri emanet ettiğimiz buluta dair zihnimizde bulanıklıktan başka kalıcı bir imge de canlanmamaktadır (Bridle, 2020: 17). Bizden hatırlamamız beklenen tek şey, birazdan çıkılacak bulutlara açılan kapının dijital şifreleridir. Şifreler bizi engin fakat yönlendirilmiş; emin fakat esir bir dünyanın eşiğine götürmektedir. Aşina olduğumuz sayılardan oluşan dijital şifreler, esasında büyük veri karşısında küçülen insanın metaforudur.

Çağın insanı, önce üretmeye mecbur bırakıldığı şey tarafindan tüketilmektedir. Öyle ki kendi elleriyle paylaştığı kişisel veriler, kendi aleyhine dönerek beğeni ve tercihlerini yeniden ve sürgit şekillendirmektedir. Burada kendi rızasıyla feragat edilen ilk şey mahremiyettir (Bauman ve Lyon, 2016: 35). Elbette bu rıza gösterimi ki buna bir tür öz-sömürgeleştirme ya da benliğin maddeleştirilmesi de denebilir, büyük veriyi inşa eden sistem tarafindan asla ödülsüz bırakılmamaktadır. Şöyle ki, kişi kendinden aktardığı her bilgi için ücretsiz kullanabileceği uygulamaları kullanma hakkına sahip olabilmektedir. Daha doğru ifadeyle bu uygulamalara erişebilmenin tek kefareti -kredi kartıyla ücretini ödemek dışında- bu paylaşma sözleşmesini tek dokunuşla onaylamaktır. Gerçekten de "Hayattaki en pahalı şey- 
ler bedavadır." (Goodman, 2016: 84), tıpkı zamanın, emeğin ve mahremiyetin elden teslimi gibi. Rızayı takip eden $7 / 24$ çevrim içi veri akışı, esas itibariyle kredi kartiyla yapılabilecek tüm ödemelerden çok daha değerlidir. Çünkü bu onay sayesinde, kişinin bulutta biriken benlik madenine istendiği zaman ve istendiği kadar inme hakkını sisteme tanıyan sınırsız vize imzalanmış demektir.

Verinin temin ettiği algoritmalar, böylece sezgilerin yerini almaktadır. Geçmişin makineler için engelleyici yük olduğu tezini savunan Tom Chatfield'in görüşünün (2013: 55) aksine söylenebilir ki, geçmiş artk büyük verinin temel besin kaynağıdır. Fakat buradaki geçmiş düşüncesi, kronolojik dizgenin ötesinde, şimdiyi ve geleceği holistik bütünlükle birbiri içine geçirmiştir. Geçmiş gibi gerçekler de dijitalleşmenin ellerinde ontolojik bir değiş tokuşa yönelmektedir: Artık sanal, gerçek; gerçek de sanaldır. Üstelik bu değişim yalnızca tüketim alışkanlıklarını ya da beğenileri değil; bir bütün olarak insan zihnini ve yaşamın kolektif bilincini derinden sarsmaktadır. Belleği dönüştüren her tekniğin bilinci de dönüştüreceği varsayımı (Göksel, 2019: 134) doğruysa Michio Kaku'nun sorduğu soru da hiç yersiz değildir: "Zihnimiz dijitalleştirilebiliyorsa ruhumuz da yalnızca veri midir?" (2019: 219).

Bu soru, esasında metafizik niteliği olan şeylerin dahi "ölçülebilir" parametrelerle tanımlanmaya başladığı bir çağın -geçerliliğini değilse de- önlenemez yükselişini doğrulamaktadır. Bu, daha iyinin yerine daha fazlanın ikame edildiği bir mutluluk endüstrisidir (Davies, 2015: 144) ve burada değer yargıları istatistiki göstergelerle yorumlanmaktadır. Oysa niceliksel verinin kutsanarak yükselişi, niteliğin gözden düşüşünü getirmektedir (Bauman, 2012: 29). Çünkü her şeyin belli bir ağda ve otomatizm kültürü içinde sayısal kodlarla şifrelenebilir oluşu dilin, bedenin ve emeğin yitimidir (Baudrillard, 2012: 44).

$\mathrm{Bu}$ yitime uğramak istemeyen ya da yeni sınıf sistemine dâhil olmak istemeyen insanları bekleyen temel zorluk, Nosedive dizisinde de vurgulandığı gibi, performans ve kontrol arasında salınan ikircikli ve belki de kaçışsız bir hayat yaşamak zorunda kalmaktır. Nitekim olan bitene tepki göstermek bile, daha da büyümek isteyen verinin boşluklarının doldurulmasına yaramakta ve ironik bir şekilde tersten itaatin aracı olmaktadır. Karşıtlıktan bile güç devşiren bu düzenekte itirazlar ve dirençler de birer ürün hâline getirilmektedir (Anders, 2018a: 247). Baudrillard da ötekinin bile bir üretim nesnesine dönüştürüldüğü bir çağa giriyoruz, derken (2006b: 141) aynı paradoksal tekinsizliğin altını çizmektedir.

\section{4. İnsani Küçülmenin İzdüşümleri: Performans, Kontrol ve Kaçış}

Lacie, beş üzerinden dört civarında olan puanlarını arttırmayı tutkuyla istemektedir. Sistemin ruhunu içselleştirememiş, savruk ruhlu ve aidiyetsiz erkek kardeşiyle 
beraber oturduğu evde kiracı olması, Lacie’yi “daha fazlası”nı yapmaya zorlamaktadır. Aynı zamanda o, yalnızca "birincil etkileyiciler"in oturabildiği lüks Pelican Evleri'ne taşınma hayalindedir. Bunun için en az 4,5 puana ihtiyaç vardır. Yüksek puan almak, toplumsal onayın ve konforlu yaşamın da anahtarıdır. Her artı puan, "beğenilme" yi sağlayacak daha çetin performansı ön şart koşmaktadır ki en ufak bir hatayı dahi kaldıramayacak olan bu erek, Lacie'yi kitle karşısında maskelerle dolu bir hayata zorlar. Lacie, sürekli bir gülücük provası altında, yüzü ile maskesi arasındaki ontolojik ayrımın ara çizgisini zamanla kaybeder. Kendisi hakkında verilecek her puan, büyük verinin kendi hakkında takdir edeceği kendiliğinden-kararın meşruiyet kaynağıdır. Bunun için ihtiyaç duyduğu şey, adına "umumi gözden düşme" denen gölge-tehditle karşılaşmamak adına, doğallığın-ölümünü göze alarak sahte ilişkiler ağında tutunmaktır.

Bireyin, varlığını devamlı bir performans üzerinden veri olarak kaynağa aktarması ona, "Bunu yapmak zorundasın." diye emreden sert bir ideolojinin varlığına dayanmamaktadır. Aksine, tüm motivasyonunu "Evet, yapabilirsin." türünden teşvik edici bir tavsiyeden almaktadır (Chul-Han, 2019). Chul-Han'a göre, Foucault'un detaylandırdığı "disiplin toplumu"nun vadesi dolmuş; yerine "performans toplumu" geçmiştir. Fakat bu performans öznesi kendini sömüren ve bu yolla sömürülendir; yani özgürlük duygusuna kapılmış biri olarak hem kurban hem de katildir (Chul-Han, 2019: 70). Anders'in uzun yıllar evvel, "Yalnızca katil değil, ölecek olanlar da suçludur." derken (2018a: 306); kastettiği şeyin bugünkü karşılığı bu olabilir mi?

Chul-Han, bu soruya geçerli bir yanıt verircesine, panoptik kontrolün arkasında, kendisini gönüllü olarak pornografik teşhirin ellerine bırakan bir şeffaflık kültürünün olduğunu belirtmektedir (2017: 68). İnsanın iç dünyasına kadar sirayet eden bu kuşatılmışlıktan kurtulmak için sahici bir yaşama dönmek ya da ölümlülüğün ibret verici gerçekliğini anımsamak tesirli eğilimler olabilir. Ancak yine Chul-Han'a göre "Artık bu çağda yaşamak için fazla ölü ve ölmek için de fazla diriyiz."dir (2018: 48). Buradaki "fazla" sıfat, oldukça yerindedir. Zira modern bireyin mahrum olduğu nimetlerin ve maruz kaldığı tehlikelerin neredeyse tamamı, eksikliklerden ziyade fazlalıklardan kaynaklanmaktadır (Baudrillard, 2010: 99). Büyük veri de bu aşırılıklardan taşan ve önüne geçilemeyen akışın çıktısı olarak devasalaşmaktadır.

Bugün siber uzamda bu denli yaygın olması ve insanların özgürlüğü bir zorbanın talimatını almış gibi kusursuz itaatle deneyimlemelerinin arkasında, sansürsüz şeffaflık sağlayan bir "Aktivite Kalpazanlığı" 6 vardır. Bu kültür, bireye ilginç bir şekilde hem izole olmanın hem de kesintisiz iletişim kurmanın cezbedici olanakla-

6“Aktivite kalpazanlığı” ifadesi, Günther Anders'e aittir (2018b: 218). 
rını sunmaktadır. Bu nedenle böylesi ele verici bir şeffaflık, birey için korku verici ve önlem almasını gerektiren bir durum olarak görünmez. ${ }^{7}$ Burada kişinin benliğini onarma ya da yüceltme çabası bile, kolektif rutinin içinde askıya alınmıştır (Mumford, 2017: 44). Dahası, insani sorgulamalar yerine, sürekli ilerlediği hedefin zıt kutbuna ulaşan gayri iradi sürüklenişler veya spontane karşılaşmalar vardır. Bilgilenmeler eyleme dönüşmeme vaadi taşımaktadırlar. Kuşatılmışıı hissini pekiştiren her yeni bilgi(lenme), modern insanın aczini paranoyakça arttrarak onu güvensizlik duygusuna ve gözetim ihtiyacına sevk etmektedir (Bridle, 2020: 192). Başka bir ifadeyle performansın ve kontrolün simbiyotik dengesi sonucu, modern insan hem sakındırılmakta hem de uyumlulaştırılmaktadır.

Yine de aralıksız kaçışı davet eden veya uyum için çabayı gerektiren bu performans sahnesi olabildiğince kaygan bir zemin üzerine kurulmuştur. Lacie'nin arzuladığı türden zirvede olmak/zirvede kalmak keyifli ve bir o kadar kasvetli bir ana karşılık gelmektedir (Mullane, 2017). Kaldı ki uzun yılların birikimiyle toplanan puanların "dibe vurması" da başka bir an meselesidir. Lacie de "seçkin" üyelerin katulacağı düğüne nedime giderken benzer bir düşüşle karşılaşır. Güvenliğin de müdahale ettiği bir olayda, yıllar içinde biriktirdiği puanlar keskin bir şekilde düşer. Bu kez puanı düşüklerin "zorlaştırılmış" dünyasına adım atar. Dışlanmaya başlar. Fakat bu dışlanma, geçiştirerek yaşadığı yapay dünyanın içyüzünü görmesine olanak sağlar. Yolda kaldığı bir gün kendisine çok düşük puanlı bir kadın yardım eder. Fakat bu kadın, sisteme bir tepki olarak "kendi gibi" yaşamaya dönmüş biridir. $\mathrm{Bu}$, dibe vuruşun olumlanmasıdır. O, bu durumu, "sıkan ayakkabıları çıkarmaya" benzetir ve Lacie'ye de bunu salık verir.

Lacie'nin yaşadığı ikinci ve güçlü kırılma, ulaşmak için büyük fedakârlıklar yaptığı düğüne yaklaştığında yaşanır. Eski dostu olan yüksek puanlı gelin arkadaşı, son anda Lacie'yi aldığı düşük puanlardan dolayı düğününde görmek istemediğini söyler. Arkadaşı ona, "Evine dön." diyerek meseleyi kapatır. Buradaki "ev" imgesi, insanın belki de özüdür. Takdir edilme isteğinden vazgeçmesidir. Sistemin yerleşik taşlarıyla oynanmasıdır. Lacie için bu "eve dönüş" çağrısı önce bir travmaya dönüşür. Düğünü basar ve puanını sıfirlayacak hatalar yapar. Sonunda tükenir. Gözündeki implant çıkarılır ve küçük bir hücreye konur. Grinin tonlarından oluşan bu renksiz hücrede, kendisini tek tip yapan standart kostümünü de çıkarır. Karşı hücredeki adamla -hiçbir maske takmaksızın- dilediği argo ifadelerle atışır. Belki

\footnotetext{
${ }^{7}$ Bireyde cereyan eden bu tepkisizlik, Büyük Veri’ye dair herhangi bir etik tartışmanın yapıımadığı anlamına gelmemektedir. Özellikle Facebook ve Cambridge Analytica arasında yaşanan "veri satışı" krizi sonrasında, konu hakkındaki etik tartş̧ma alevlenmiştir. Bu krizi inceleyen yine bir Netflix yapımı The Great Hack (2019) isimli belgesel izlenebilir. Büyük Veri eksenli organizasyonlara yönelik etik ilke ve öneriler genel olarak şeffafık, sadelik, güvenlik ve muhataplık şeklinde dört temel başık altında toplanabilir (Rijmenam, 2013). Bu ilkelerin tamamı ve daha fazlası, "Yapabilir miyiz?" yerine "Yapmalı mıyız?" sorusunu öncelemektedir (Leonhard, 2018: 130).
} 
de hayatında ilk kez havada süzülen tozları ve fotonları görür. Bu bir uyanma biçimidir: Gerçeğe uyanma.

\section{Sonuç: Büyüyen Veri ve Küzcülen İnsanın Olası Akıbeti Üzerine}

Netflix, geleceğin inşasında belirgin bir misyon üstlenmektedir. Bu platformda teknoloji-tabanlı yeni yaşam yalnızca varsayılmamakta, ön bilgileri aktarılan taslaklar üzerinden gelecek-zaman tasarımları izleyicilerin zihninde inşa da edilmektedir. Black Mirror, bu açıdan sosyal ve beşerî bilimler için birçok kışkırtıcı tartışmaya açılım sağlamaktadır. Örneğin tüm bölümlerine genel olarak bakıldığında dizide büyük veriye dair öngörüler beş başlık altında toplanabilir: Illki, geçmiş zamanın her anını kaydeden cihazlar ve bu cihazlarla hatıraları yönetebilme kabiliyeti olacaktır. İkincisi her birey devamlı çevrim içi kullanacağı kontakt lensler aracılığıyla insanları ve tükettikleri şeyleri derecelendirebilme yetkisine kavuşacaktır. Üçüncüsü, büyük veri yapay zekâ ile iş birliği hâlinde herkes için özel ve kişisel ve istendiğinde topluca tecrübe edilen sanal bir zaman ve mekânın alanını genişletecektir. Dördüncüsü, giyilebilir teknolojiler yoluyla sağlıktan güvenliğe yaşamın her alanında tüm ilişkiler düzenini yeniden formatlayacaktır. Sonuncusu, sağladığı bu riskli kolaylığa istinaden biraz da kişisel verinin sınırlarındaki belirsizliklerden ötürü mahremiyet ihlalleri ve siber suçlar artacaktır (Bhat, 2020). Nosedive, tüm bu öngörüleri birleştirerek insanların tabi olması muhtemel bir sınıflandırma anlayışının eleştirisini yapmaktadır.

Bu eleştirinin özü şudur: Yıllardır insanlığın ilerlemesi adına yüceltilen bilgi çağı ve bilgi toplumunun son kurbanı bizatihi insanın kendisidir. Üstelik parmak uçlarıyla göz bebekleri arasında salınan bu akış esnek fakat kırılgandır. Burada insanlar, Nosedive'deki sunumun aksine, korkudan ziyade keyif yoluyla, yani yokluk ve mahrumiyetle değil; varlıkla ve sınırsız imkânla imtihan edilmektedir. Düzenin bu yönsüz, odaksız ve olumlayıcı dokusunun sonucunda sanki her şey, veri üretimine hizmet etmeye güdülenmiş gibi durmaktadır. Bu koşullar altında insan, şeffaf fakat derinliksiz dijital izden değildir. Dikkat endüstrisinin seri-üretim mahsulü olarak yalnızca "takip"lerden ve "paylaş"lardan müteşekkil, bilinmezliğe taş atan bir yersiz yurtsuzdur o. Yaşamı anlamdan yoksun edimlerle ve edimlerin yoksunluğu nispetinde söylemlerle doludur.

Büyük veri, bir dış ağ yerine bir içkinlik olarak tecrübe edilmektedir. Ne var ki bu içkinlik de artık insani niteliğe ya da aşkın olana değil; şifrelenmiş içeriklerin hüküm sürdüğü nicelikler krallığına gönderme yapmaktadır. Her şeyin elektronik olarak erişilebilir olduğu böylesi bir dünyaya katılım sağlamak için artık uzun ve çetin yollar kat etmeye de gerek kalmamıştır. Başkaları hakkında kanılar edinmek, 
bu kanılarla söylemler geliştirmek ve bu söylemleri paylaşıma açmak, elimizin altında daima hazırda bekleyen bir ekrana ufak bir dokunuş mesabesindedir. Verilen tüm hükümler, sıra o hükmü verenin kendisine dönene kadar, başkalarının hayatlarını yapma ve yıkma kudretine sahiptir. İçinde hemen her duygunun teşhir ve -bir anlığına da olsa tatmin- edilebildiği bu yeni moda, modern insanın göz ve parmak hareketleriyle yönetilmektedir.

Öte yandan, büyük veriyle tasarlanan bu temasların hiçbirisi tesadüfi olmadığı gibi, ince hesaplanabilir algoritmaların sıkı kontrolü ve tasarımı altındadır. Aygıtsız bir yaşamın imkânsızlığına gidilirken; biraz da sayborg öğretilerinin gölgesinde günbegün tek tipleşerek mekanikleşen bir insan kurgusundan bahsedilebilir. Tam da bu noktada büyük verinin geleceği namına tehdit oluşturan bir soru belirmektedir: Sistemin isteklerini harfiyen yerine getirecek yeni model tek tip insanların sunabileceği yeni bir şey kalmadığında veri de bitmeyecek midir? Başka bir ifadeyle kaynağını sonuna kadar sömüren ve onda özgün ve otantik bir şey bırakmayan bir sistem, sonunda içinden çıkılamayacak bir kısır döngüye gömülmez mi? Soru biraz daha kısaltılabilir: İnsan bittiğinde geriye ne kalır?

Elbette işleyişin, tıpkı seri üretim fabrikalarındaki gibi fiber hızlı ve otomasyon mekaniğine uygun olarak yürütülmesi, bu yıkım-yapım oyununun etraflıca sorgulanmasını güçleştirmektedir. Ayrıca, böyle bir sorgulama için gerekli olan "durma" veya "yavaşlama" önerilerini boşa çıkarmak adına ömür boyu kontrolün ve performansın hayatiliği her an ve mecrada cilalanmaktadır. Sürekli devinen ve değişen "ideal kimlik" niteliklerine değilse de sayılarla tanımlanan standartları yakalamak için kendini performanslarla sergileyen modern insan, her adımıyla büyük verinin malzemesi olmaya koşmaktadır. Susmanın ve konuşmanın; itaat ve tepkinin hiçleştiği böylesi bir durumda ne yapılabileceğine dair Nosedive farklı bir öneri sunmaktadır.

Nosedive'in, daha doğrusu Lacie'nin dizinin sonunda izleyiciye verdiği çarpıcı mesaja göre, "dibe vurmak" modern insanın yıkımı değil; kurtuluşunun belki de tek yoludur. Çünkü ancak dibe vuran biri, yüksekte olmanın ve orada kalmanın kişiyi soluksuz bırakan yarıştırmalarından ve yakıştırmalarından sıyrılabilir. Dibe vurmak, maskelerin iflasıdır. Lacie de dibe vurduğu anda kendisi olabilmiştir. O güne kadar yüksek puanlar elde etmek amacıyla yaptığı tüm sentetik ilişkileri dibe vurduğunda uyumdan feragat etmiş saf bir "kendi oluş"a evrilir. Sonunda sistem tarafindan delilikle itham edilip örselense ve ötelense de indirgenemeyeceğini anladığı sayısal verilerin büyüsünü bozup bazı yönleriyle çirkin de olsa doğal varlığının insani yönleriyle yüzleşir. Lacie'nin başına gelenler kadar onun yaşadığı dibe vuruş ve bununla gelen özgürleşme, tüm modern insanlığın güçlü 
bir olasılığıdır. Belki de bulutlar gibi yüksekte ve her an çevrim içi olmanın pazarlandığı bir çağda, bir ikbal olarak dibe vurmaya talip olmak gerekmektedir. Peki ya Lacie kadar cesur değilsek? Tüm inziva köşelerinin turistik bir hevesle tüketildiği bir dünyada, acaba ruhumuzun ya da bilincimizin bir yerlerinde güvenle sığınılabileceğimiz ve kendimizi yeniden tamir edebileceğimiz saf, bakir ve bereketli ücralar kalmış mıdır?

\section{Kaynakça}

Ahearn, F. M. (2012). İz Bırakmadan: Dijital Ayak izlerinizi Silip Sırra Kadem Basmanın Yolları, Çev. A. Pardo, İstanbul: NTV Yayınları.

Anders, G. (2018a) İnsanın Eskimişliği: İkinci Endüstri Devrimi Çağında İnsan Ruhu Üzerine (1. Cilt), Çev. H. Ertürk, İstanbul: İthaki Yayınları.

Anders, G. (2018b) İnsanın Eskimişliği: Üçüncü Endüstri Devrimi Çağında Yaşamın Tahribato Üzerine (2. Cilt), Çev. H. Ertürk, İstanbul: İthaki Yayınları.

Bauchspies, W. K., Croissant, J., ve Restiuo, S. (2019). Bilim Teknoloji ve Toplum: Sosyolojik Bir Yaklaşım, Çev. B. Kuryel, B. Balkız ve Ü. Tatlıcan, Ankara: Phoenix Yayıncilık.

Baudrillard, J. (2005). Şeytana Satılan Ruh ya da Kötülüğün Egemenliği, Çev. O. Adanır, Ankara: Doğu Bat Yayınları.

Baudrillard, J. (2006a). Cool Anılar V 2000-2004, Çev. A. Sönmezay, İstanbul: Ayrınt Yayınları.

Baudrillard, J. (2006b). Sessiz Yığınların Gölgesinde, Çev. O. Adanır, Ankara: Doğu Bat Yayınları.

Baudrillard, J. (2010). Kötülüğün Şeffaflığı: Aşırı Fenomenler Üzerine Bir Deneme, Çev. I. Ergüden, İstanbul: Ayrıntı Yayınları.

Baudrillard, J. (2012). İmkânsız Takas, Çev. A. Sönmezay, İstanbul: Ayrınt Yayınları.

Bauman, Z. (2010). Etiğin Tüketiciler Dünyasında Bir Şansı Var Mı? Çev. F. Çoban ve İ. Katrrcı, Ankara: De Ki Yayınları.

Bauman, Z. (2012). Akışkan Modern Dünyadan 44 Mektup, Çev. P. Siral, İstanbul: Habitus Yayınları.

Bauman, Z. (2018). Retrotopya, Çev. A. Karatay, İstanbul: Sel Yayıncılık.

Bauman, Z., ve Lyon, D. (2016). Akışkan Gözetim, Çev. E. Yılmaz, İstanbul: Ayrınt Yayınları. Bhat, A. (2020). "Five Amazing Black Mirror Predictions about the Future of Big Data, Manipal Prolearn", https://www.manipalprolearn.com/blog/5-amazing-black-mirror-predictions-about-future-big-data (Erişim Tarihi: 10 Ekim 2020).

Braidotti, R. (2018). İnsan Sonrası, Çev. Ö. Karakaş, İstanbul: Kolektif Yayıncılık.

Bridle, J. (2020). Yeni Karanlık Çağ: Teknoloji ve Geleceğin Sonu, Çev. K. Güleç, İstanbul: Metis Yayınları.

Chatfield, T. (2013). Dijital Çağa Nasıl Uyum Sağlarız? Çev. L. Konca, İstanbul: Sel Yayıncılık. Chen H., Chiang R.H., and Storey V.C. (2012). "Business Intelligence and Analytics: From Big Data to Big Impact", MIS, 36 (4): 1165-1188.

Chul-Han, B. (2017). Şeffaflık Toplumu, Çev. H. Barışcan, İstanbul: Metis Yayınları. Chul-Han, B. (2018). Güzeli Kurtarmak, Çev. K. Filiz, İstanbul: İnsan Yayınları. 
Chul-Han, B. (2019). Yorgunluk Toplumu, Çev. S. Karlıtekin, İstanbul: Açılım Kitap.

Chul-Han, B. (2020). Psikopolitika, Neoliberalizm ve Yeni Iktidar Teknikleri, H. Barışcan, İstanbul: Metis Yayınları.

Crary, J. (2015). 7/24: Geç Kapitalizm ve Uykuların Sonu, Çev. N. Çatlı, İstanbul: Metis Yayınları.

Davies, W. (2015). Mutluluk Endüstrisi, Çev. M. Çavdar, İstanbul: Sel Yayıncılık.

Diken, B., ve Laustsen, C. B. (2016). Filmlerle Sosyoloji, Çev. S. Ertekin, İstanbul: Metis Yayınları.

Dominic P. (2017). Sonsuz Dikkat Dağınıklığı: Gündelik Yaşamda Sosyal Medyaya Odaklanmak, Çev. Y. Çetin, İstanbul: Sel Yayıncılık.

Ertürk, N. E. (2019). "Dijital ve Varoluş: Dijitalin Soy Kütüğüne Doğru”, Doğu Bat Dergisi. Dijital Çağ Dosyası, (86): 157-171.

Eyal, N. (2015). Kancaya Takılınca, Çev. B. Akat, İstanbul: Elma Yayınevi.

Franklin, D. (2019). Mega-Tech, Çev. B. Seyrek, İstanbul: Siyah Kitap.

Gilbert, S. (2016). "Max Richter's Soundtrack to Dystopia”, The Atlantic, https://www.theatlantic.com/entertainment/archive/2016/11/max-richter-interview-black-mirror-the-leftovers-miss-sloane/506033/ (Erişim Tarihi: 12 Ekim 2020)

Goodman, M. (2016). Geleceğin Suçları: Dijital Dünyanın Karanlık Yüzü, Çev. C. Özdemir, İstanbul: Timaş Yayınları.

Göksel, N. (2019). “Gelen”, Doğu Bat Dergisi, Dijital Çağ Sayısı, (86): 133-141.

Harari, Y. N. (2016). Homo Deus: Yarının Kısa Bir Tarihi, Çev. P. N. Taneli, İstanbul: Kolektif Kitap.

Johnson, D.K., Marquez, L.P. and Urueña, S. (2020). "Black Mirror", in Black Mirror and Philosophy, D.K. Johnson (Ed.). doi:10.1002/9781119578291.ch0

Kaku, M. (2019). İnsanlığın Geleceği, Ankara: ODTÜ Yayıncılık.

Le Breton, D. (2016). Bedene Veda, Çev. A. U. Kılıç, İstanbul: Sel Yayıncılık.

Lee, E. A. (2019). Dijital Ruh: İnsan ve Teknoloji Arasındaki Yaratıcı Ortaklık, Çev. A. Uysal ve G. Uysal, İstanbul: Koç Üniversitesi Yayınları.

Leonhard, G. (2018). Teknolojiye Karşı İnsanlık, Çev. C. Akkartal ve İ. Akkartal, İstanbul: Siyah Kitap.

Mullane, A. (2016). "Black Mirror Season 3 'Nosedive' Review: This One Contains The Show's Biggest Twist Yet", Digital Spy, https://www.digitalspy.com/tv/cult/ a811645/black-mirror-season-3-review-the-surprise-climax-to-nosediveis-the-shows-biggest-twist-yet/ (Erişim Tarihi: 18 Ekim 2020).

Mumford, L. (2017). Teknik ve Uygarlık, Çev. E. C. Ercan, İstanbul: Açıım Kitap.

Pettman, D. (2017). Sonsuz Dikkat Dağınıklığı, Çev. Y. Çetin, İstanbul: Sel Yayıncılık.

Rijmenam, M. V. (2013). “Big Data Ethics: 4 Guidelines To Follow By Organisations”, Datafloq,https://datafloq.com/read/big-data-ethics-4-principles-follow-organisations/221, (Erişim Tarihi: 15 Ekim 2020).

Toffler, A. (1981). The Third Wave, New York: Bantam Books.

Urueña, S. and Melikyan, N. (2020). "Nosedive and the Anxieties of Social Media", In Black Mirror and Philosophy, D.K. Johnson (Ed.). doi:10.1002/9781119578291.ch8 Vincent, A. (2017). "Black Mirror is Coming True in China, Where Your 'Rating' Affects Your Home, Transport and Social Circle", The Daily Telegraph, https:// www.telegraph.co.uk/on-demand/2017/12/15/black-mirror-coming-true-china-rating-affects-home-transport/ (Erişim Tarihi: 21 Ekim 2020). 
Virani, Farida (2019) Black Mirror of Big Data Analysis, Digital Spy, https://www.met.edu/ blog/Black_Mirror_of_Big_Data_Analysis (Erişim Tarihi 21 Ekim 2020)

Yıldırım, A. (2019). “Gözetlemenin Güncel İşleyiş Mantı̆̆ olarak Post-Panoptikon”, Doğu Bat Dergisi, Dijital Çağ Dosyası, (86): 63-77.

\section{Filmografi}

Amer, K. ve Noujaim, J. (Yönetmen). 2019. The Great Hack [Belgesel], USA.

Orlowski, J. (Yönetmen). 2020. Social Dilemma [Belgesel], USA.

Smolan, S. (Yönetmen). 2014. The Human Face of Big Data [Belgesel], USA.

Wright, J. (Yönetmen). 2016. Nosedive [Film], UK. 